\title{
The Effect of State Budget Ratification and Expenditure on The Indonesian Capital Market : An Empirical Study on The LQ 45 Index Shares
}

\author{
Agus Bandiyono $^{1^{*}}$, Priska Amalia ${ }^{2}$ \\ 1 Politeknik Keuangan Negara STAN, Indonesia \\ ${ }^{2}$ Badan Kebijakan Fiskal Kementerian Keuangan, Indonesia \\ ${ }^{*}$ Corresponding Author: agusbandiyono@pknstan.ac.id
}

\begin{abstract}
This study analyzes the market reaction to the State Revenue and Expenditure Budget (APBN) ratification using the event study method. The population in this study were all companies listed on the LQ45 index on the Indonesia Stock Exchange during the period 2009 to 2018, which could reach 101 emissions with a sample of 17 emissions through the purposive sampling technique. The criteria used in selecting the sample were that the stock was consistently in the LQ45 index from 2009 to 2018; the stock was active during the observation period. The share issuer does not take corporate action during the observation period to minimize the confounding effect (confounding effect). The analysis technique uses a paired sample t-test five days before and five days after the ratification of the State Budget (APBN). The results showed that the significant ratification events did not significantly differ in the average abnormal return and the average trading volume activity between before and after the event. There is no significant difference because market players have anticipated the information contained in the ratification event at the initial stage of its preparation.
\end{abstract}

Keywords: APBN; capital market reactions; event studies; financial accounting

\section{INTRODUCTION}

On 31 October 2018, the government and the House of Representatives (DPR) approved the State Revenue and Expenditure Budget (APBN) for the 2019 budget year. In the APBN, the government took the big theme "APBN to Encourage Investment and Competitiveness through Development (Investment) Human Resources (HR). "This theme will be realized through the three main strategies of the State Budget, namely (1) realistic revenue mobilization while maintaining the investment climate, (2) increasing the quality of spending to be more productive and effective by strengthening value for money to support priority programs including education and health, and (3) encourage efficiency and innovation in financing. With these three strategies, the APBN is effective as an instrument to achieve inclusive economic growth and has the resilience and ability to 
anticipate and respond appropriately to the dynamics of national and global economic developments at hand.

The government budget reflects the estimated future expenses and revenues that will predict the economic and financial situation of the country (Hu, Q., Zhang, L., Zhang, W., \& Zhang, S., 2020). The announcement of the budget may be an event that many parties eagerly await. Fiscal issues, such as taxes, spending, and fiscal deficits, are essential in macroeconomics. Moreover, governments often prefer budget announcements as a mechanism to announce crucial new policy initiatives and outline some economic policy plans for the next few months. General empirical studies show that capital market activity tends to be heavily influenced by government budgets. The capital market reaction to the budget is often interpreted as a statistical overview of the budget's quality to encourage economic growth (Guo, M., Kuai, Y., \& Liu, X, 2020).

The Indonesian Government Budget starting now referred to as the State Revenue and Expenditure Budget (APBN), is often a means of communication for the government to inform its policies to the public. In President Susilo Bambang Yudhoyono's administration for the 2010-2014 period, the 2011 State Budget provided information regarding the gradual reduction of electricity subsidies. Meanwhile, the 2016 State Budget, which was passed during President Joko Widodo's presidency, includes details on the five percent health budget allocation policy mandated by Law Number 36 of 2009.

Information related to financial budgets and policies conveyed in government budget documents can stimulate or weaken companies' shares on the stock exchange. Consequently, investors' reactions to the stock exchange will depend on the impact of budget policy on the industry (Edirisinghe, 2017). If the government budget predicts the economy will be good in the next year, the company's revenue and dividend growth forecasts will increase, thus pushing up share prices. Conversely, share prices will decline if the country's economic forecast for the next year is terrible (Hu, Q., Zhang, L., Zhang, W., \& Zhang, S., 2020). This is, of course, closely related to the signal theory (signaling theory), which explains how signals from information can influence price changes in the capital market.

The content of information in the capital market is also explained in the efficient market concept popularized by Fama in 1970. In this concept, it is stated that the prices formed in the market are a reflection of existing information. To put it another way, in an efficient market, the prices of assets and securities represent the knowledge available on these assets and securities wholly and quickly. According to the semi-strong efficient market theory, the fee generated in the market is a reflection of historical prices. It exists due to information on the market, such as financial reports and other additional information (Sujana, I. N, 2017).

The market reaction in the efficient market concept can be analyzed through the study of events. An event study is a study that examines the irregular yields that can occur in the aftermath of an event (Katti, S. W. B, 2018). The event study analyzes the market reaction to an event by testing its information content. If the market reacts when the market receives information from an event, it can be said that it contains sufficient information. Market reactions occur if there is a change in the security concern's price by measuring the return or abnormal return (Saraswati and Mustanda, 2018). 
The information content that is tested is related to conditions or situations that are considered relevant to the share price assessment, whether it is official news or issues. Information that causes reactions in the capital market and affects stock price fluctuations comes from data on economic conditions and comes from non-economic factors such as legal, social events to domestic political turmoil that affect stock price movements on the stock exchange. Effects (Saraswati and Mustanda, 2018).

Not only do capital market investors need to pay close attention to stock price movements due to the effects of an event. However, the government also needs to carry out deeper monitoring following government functions CQ. Minister of Finance Regulation Number 212 / PMK.01 / 2017 concerning Amendments to Minister of Finance Regulation Number 234 / PMK.01 / 2015 concerning the Organization and Work Procedures of the Ministry of Finance. Article 5 of the regulation states that one of the functions of the Ministry of Finance is to formulate, determine, and provide recommendations for fiscal and financial sector policies. Furthermore, Law Number 9 of 2016 concerning Financial System Crisis Prevention and Management states that the Minister of Finance acts as a coordinator and concurrently a member of the Financial System Stability Committee (KSSK). The KSSK is responsible for preventing and resolving financial system crises, including coordinating monitoring and sustaining financial system stability, dealing with financial system crises, and dealing with systemic bank problems.

This research was conducted to examine the effect of ratification of the State Budget and Revenue and Expenditure (APBN) on the Indonesian capital market by looking at the abnormal return and trading volume activity before and after the event. The scope of this research is limited to: The listed companies are listed on the Indonesia Stock Exchange and are included in the LQ45 index for the period February 2009 to January 2019. The LQ45 index is used as a sample because it has high liquidity, so that investors react to the information presented. It appears to be directly reflected in the price of these shares; The events for ratifying the State Revenue and Expenditure Budget (APBN) to be examined are the ratification of the State Budget for the 2010-2019 fiscal year. The observation period is carried out for 41 trading days which are divided into two periods, namely a 30 day estimation period and an 11 day window period (event window/event period). The estimation period is carried out on h-30 to h- 6 events, while the window period is carried out on $\mathrm{h}-5$ to $\mathrm{h}+5$ events.

The objectives to be achieved from this research are as follows: To examine any abnormal returns surrounding the ratification of the State Revenue and Expenditure Budget (APBN); Examine whether there is a market response as seen from the abnormal return before and after the event of the ratification of the State Revenue and Expenditure Budget (APBN); Examine whether there is a market response seen from the trading volume operation before and after the event of the ratification of the State Budget (APBN).

\section{HYPOTHESES DEVELOPMENT}

\section{Signaling Theory}

Market players need to understand the market conditions, both in the past and in the future. Complete, accurate, and timely information can help market participants make an investment decision. Information can provide a signal, both positive and negative, through the market reaction to that information. Information is closely related to signal theory 
(signaling theory). The signaling theory was developed to help explain how decisionmakers interpret and respond to incomplete and asymmetrical distributed information in a transaction (Spence, 1973). Signaling theory provides a basis for predicting the capital market's reaction to information or events that occur.

\section{Market Efficiency Concept}

Fama (1970) coined the term efficient market as a market that adjusts quickly to the presence of new information. Furthermore, an efficient market is one in which all prices in the market represent the available information, based on the premise that there are no transaction costs in securities trading. The information is available to all market participants at no cost, and that there is consensus on the impact of current information on prices.

\section{Capital Market}

The capital market, according to Law No. 8 of 1995 on Capital Markets, is an activity involving public offerings and securities trading, public corporations and the securities they sell, as well as entities and professions associated with protection. According to Jogiyanto (2017: 29), the capital market is a company's way of increasing long-term financing needs. The capital market must be liquid and competitive to encourage buyers and sellers to participate. If sellers can quickly sell and buyers can promptly buy shares, a capital market is liquid. If the prices of these securities correctly represent the firm's worth, the capital market is said to be effective.

\section{Concept of Event Study}

Event study measures the relationship of events that affect securities and returns from these securities (Gurkaynak, R. S., Kisacikoğlu, B., \& Wright, J. H, 2020). This study is often used to test the efficient market hypothesis. Meanwhile, Sorescu, A., Warren, N. L., \& Ertekin, L. (2017) states that event studies measure the impact of certain events on firm value by using financial market data. Katti, S. W. B. (2018) defines an event study as an event study that analyzes the abnormal yields that may occur around an event.

\section{State Revenue and Expenditure Budget (APBN)}

Law Number 17 of 2003 concerning State Finance defines the State Revenue and Expenditure Budget (APBN) as the annual financial plan of the state government approved by the House of Representatives (DPR). The APBN is prepared based on the government's work plan and the macroeconomic framework. The fiscal policy principles are discussed and mutually agreed upon, both in preliminary talks and in the first-level discussions between the government and the House of Representatives.

\section{Return}

Return is the result obtained from an investment. Returns can be in the form of realized returns that have occurred or expected returns that have not occurred but are expected to occur in the future. Realized return is calculated using historical data and is a critical performance measurement tool for the company. Realized return is also helpful as a basis for determining future risk and expected returns. (Jogiyanto, 2017: 283). Meanwhile, the expected return is the return expected by investors in the future on the investment made. This return is used for investment decision-making (Jogiyanto, 2017: 300). 


\section{Abnormal Return}

Event study analyzes the abnormal return of securities that may occur around the announcement of an event. Jogiyanto (2017: 667) defines abnormal return as the excess return against the expected return (normal return). Elad, F., \& Bongbee, N. (2016) estimate expected returns using three estimation models. The three models, namely the meanadjusted model, market model, and market-adjusted model.

\section{Trading Volume Activity}

Stock trading volume is an indicator of market reaction to an announcement. Trading Volume Activity (TVA) is a tool for observing the capital market's reaction to the news by looking at the stock trading volume parameter. The calculation of TVA is carried out by comparing the number of shares of a company traded in a certain period with the company's total number of outstanding shares during the same period (Purba, F., \& Handayani, S. R., 2017).

Several researchers used event study analysis to investigate the capital market's reaction to the approval of the government budget. A study conducted by $\mathrm{Hu}, \mathrm{Q}$., Zhang, L., Zhang, W., \& Zhang, S. (2020), observations were made on publication, approval, and action in the government budget performance of the capital market in Portugal. The samples taken in this study were 46 companies listed in the PSI 20 index in the observation period from 1998 to 2013. Using OLS regression, the results obtained are that there is a significant return in the observation period $\mathrm{H}-10$ to $\mathrm{H}+10$. that is, when the budget proposal is published for discussion. However, the budget approval event did not have a significant impact on the capital market.

Nascimento (2015) conducted a study on the impact of publication and budget approval of the United States Federal Government on stock returns of the 500 largest companies in the country or those listed in the S \& P500 Index. Using daily stock closing price data from 4 January 2002 - 30 September 2012 and 11 events of publication and budget approval, Nascimento used the Ordinary Least Squares (OLS) methodology and event study analysis. The results of his research show that the budget approval event does not affect the return of the capital market because market players have anticipated it long before the event occurs. However, Nascimento stated that the budget and stock returns have an important relationship for the US economy even though the reactions given between the sectors are not the same.

\section{Framework}

Hu, Q., Zhang, L., Zhang, W., \& Zhang, S. (2020) states that the government budget reflects the estimated future expenses and revenues that will predict the country's economic and financial situation. This budget-related announcement is undoubtedly an event that is eagerly awaited by the public. Moreover, governments often prefer budget announcements as a mechanism to announce crucial new policy initiatives and outline some economic policy plans for the next few months.

General empirical studies show that capital market activity tends to be heavily influenced by government budgets. The capital market response to the budget is often viewed as a statistical summary of the budget's quality to promote economic improvement (Guo, M., Kuai, Y., \& Liu, X, 2020). Information related to budgets and economic policies conveyed in government budget documents can stimulate or weaken the price of shares of companies listed on the stock exchange. Consequently, the reaction of investors on the 
stock exchange will depend on the impact of budget policy on the industry (Edirisinghe, 2017). Therefore, the author wants to see the effect of government budget approval on capital market movements in Indonesia.

\section{Research Hypothesis}

Based on data, theory, and previous research, the hypothesis in this study can be structured as follows.

H1: There is an abnormal return around the ratification of the State Revenue and Expenditure Budget (APBN).

$\mathrm{H} 2$ : There is a difference in the average abnormal return before and after the ratification of the State Revenue and Expenditure Budget (APBN).

H3: There is a difference in the average trading volume activity before and after the ratification of the State Revenue and Expenditure Budget (APBN).

\section{METHOD, DATA, AND ANALYSIS}

\section{Population and Sample}

In this study, the population was all companies included in the LQ45 index on the Indonesia Stock Exchange from 2009 to 2018, and totaling 101 companies. Data regarding the company is obtained from the official website of the Indonesia Stock Exchange (www.IDX.co.id), Bloomberg, and Yahoo Finance. The sampling technique used purposive sampling, namely the population that will be used as the research sample is a population that meets certain criteria as determined by the researcher. The criteria used in sample selection are as follows.

1. These shares were consistently in the LQ45 index from 2009 to 2018;

2. The shares are actively traded during the observation period; and

3. Issuer shares do not take corporate action during the observation period to minimize confounding effects.

Table 1. Research Sample Criteria

\begin{tabular}{clc}
\hline No. & \multicolumn{1}{c}{ Criteria } & Total \\
\hline 1 & Included in the LQ45 Index in 2009 - 2018 & 100 \\
2 & $\begin{array}{l}\text { Inconsistently recorded in the LQ45 index and not actively traded } \\
\text { during the observation period }\end{array}$ & 83 \\
3 & $\begin{array}{l}\text { Carry out corporate actions during the observation period } \\
\text { selected stocks }\end{array}$ & 0 \\
\hline
\end{tabular}

Source: Compiled by the author

\section{Operational Definition}

The independent variable in this study is the event of ratification of the State Budget (APBN) for Fiscal Year 2010 to APBN for Fiscal Year 2019, which will be ratified at the end of October 2018. Meanwhile, the dependent variable in this study is abnormal return and volume of stock trading. The following is an explanation of each dependent variable. 


\section{Abnormal return}

Jogiyanto (2017: 667) defines abnormal return as the excess return against the return expected(normal return). Thus, the abnormal return can be formulated as following equation (1).

$$
\operatorname{RTN}_{i, t}=R_{i, t}-E\left[R_{i, t}\right]
$$

$\mathrm{RTN}_{, \mathrm{t}}=$ abnormal return of securities I in event period $\mathrm{t}$

$\mathrm{R}_{\mathrm{i}, \mathrm{t}}=$ return realization that occurred for securities $\mathrm{I}$ in the event $\mathrm{t}$ period

$\mathrm{E}\left[\mathrm{R}_{\mathrm{i}, \mathrm{t}}\right]=$ return expected of securities I for the $\mathrm{t}$ event period

Trading volume activity (TVA)

Trading Volume Activity (TVA) is a tool for observing the capital market's reaction to the news by looking at the stock trading volume parameters (Purba, F., \& Handayani, S. $R$, 2017). Furthermore, the Trading Volume Activity (TVA) formula is shown in equation (2).

$$
\text { TVA } \equiv \begin{gathered}
\text { number of shares of company }-i \text { traded on day } t, \\
\text { number of shares of company }-i \text { that circulated } \\
\text { on day } t
\end{gathered}
$$

\section{Data Processing Analysis Technique Data}

The method processing method is performed using the analysis event study. In general, the methodology event study follows the following procedure (Chen, J. M., 2016):

1. Collect a sample of companies that have an event that you want to research;

2. Specifies the exact day or date of the event as event date ( $\mathrm{t} 0)$;

3. Determine the research period (event window);

4. Observe the return of each sample company in each unit period;

5. Calculating the abnormal return of each company;

6. Calculating the average abnormal return for the entire sample in each unit period;

7. Calculate the abnormal return cumulative from the beginning of the period (if needed).

The model used to estimate returns expected is the market model. This model assumes that returns the expected stock, and returns market have a linear relationship. This model also assumes that the return expected depends only on the stock's systematic risk in question. The systematic risk of a stock (beta / $\beta$ ) shows how far the fluctuations in returns are stock influenced by fluctuations in the returns market.

The observation period in this study was 41 days long, divided into two parts: an estimated period and an event window/event period. The estimation period used to determine the regression coefficient between $\alpha$ and $\beta$ is 30 days. The window period is 10 days, consisting of $t-5$ (pre-event), $t 0$ (event-day), $t+5$ (post-event). Determination of the span of the window period to avoid overlapping between one event window period with another. Jogiyanto $(2017,22)$ states that the window period should not be too long or too short to be able to capture events and minimize confounding effects fully.

\section{Data Normality}

The data normality test aims to figure out which statistical test would be used in the study. The test is carried out with the parametric one-sample t-test if the data is normally distributed. If the data used is not normally distributed, the test used is the nonparametric 
test. The normality test used is the Kolmogorov-Smirnov test. With this test, it can be seen whether the observed sample value is in accordance with a certain distribution. Criteria that can be used is through a two-tailed test, namely by comparing the p-value obtained with a predetermined significance level. If the p-value is $>0.05$, the data is normally distributed, and if the $\mathrm{p}$-value is $<0.05$, the data is not normally distributed.

\section{Hypothesis Test}

hypotheses in this study can be formulated as follows.

$\mathrm{H}_{1}$ : There is an abnormal return around the event of the ratification of the State Budget(APBN).

$\mathrm{H}_{2}$ : There is a difference in the average abnormal return before and after the ratification of the State Revenue and Expenditure Budget (APBN).

$\mathrm{H}_{3}$ : There is a difference in the average trading volume activity before and after the ratification of the State Revenue and Expenditure Budget (APBN).

The three hypotheses can be accepted if count $>$ table or probability $<0.05$. Testing for each of these hypotheses can be done through the following stages.

\section{a) Hypothesis I}

The following stages are used to determine if there is an unexpected return (Jogiyanto, 2010).

1. Calculate return the real(actual return)per share

2. Return is a return that arises when all of the difference $t$ current prices relative to the previous price. If the current price $(\mathrm{Pt})$ is higher than the previous period $(\mathrm{Pt}$ 1 ), there will be again. Conversely, the loss (loss) occurs when the current price $(\mathrm{Pt})$ is lower than the price of the previous period $(\mathrm{Pt}-1)$.

3. Calculating the return market

4. In this study, the return market used is to return the LQ45 index. The calculation is done by calculating the difference between the return indexes now with the return period index previous against the return period index of the previous period.

5. Regressing returns daily stock to returns market

6. regression was performed to obtain the value of $a$ and $\beta$ for each stock subsequently entered into the regression equation to obtain return the expected(expected return).

7. Calculate the abnormal return of each stock

8. The difference between actual returns (actual return), which occurred with return the expected(expected return) is known as an abnormal return.

9. Calculate the cumulative abnormal return for each share.

10.Cumulative abnormal return (CAR) is the total of abnormal return the previous days in the event period for each security.

11.Calculating the average abnormal return of each share

12.Testing for abnormal returns is generally not done for each marketable securities but is done in an aggregate manner by examining the average abnormal return of all securities cross-sectional for each day in the event period.

13. $\mathrm{T}$ significance test analysis The $\mathrm{t}$ significance 
14.the test can be done either by using an application (for example, the one-sample ttest in SPSS) or by comparing the abnormal return standardization with the root value of the stocks sampled.

\section{b) Hypothesis II}

The following stages are used to see if there is a difference in average abnormal return (AAR) before and after the event.

1. Calculate the actual return of each stock sampled during the observation period.

2. Calculate the expected return using the market model. In calculating the expected return, linear regression is performed time series over the estimation period to determine the alpha and beta of each stock.

3. Calculate the abnormal return of each stock from $h-5$ to $h+5$.

4. Calculating the average abnormal return (AAR) of all stocks sampled before and after the event

5. Make a statistical comparison between averages abnormal return (AAR) before and after the ratification of the State Budget (APBN) using the paired samples ttest with a significance level of 5 percent.

\section{c) Hypothesis III}

Stages to test whether there is a difference in average trading volume activity (ATVA) before and after the incident is as follows:

1. Calculate the trading volume activity of each stock that is sampled during the window period.

2. Calculate average trading volume activity (ATVA) for all sampled stocks.

3. Make a statistical comparison of average trading volume activity (ATVA) before and after the ratification of the State Revenue and Expenditure Budget (APBN) by using paired samples t-test with a significance level of 5 percent.

\section{RESULTS}

\section{Descriptive Statistical Analysis}

Descriptive statistical analysis for values Averages Abnormal Return (AAR) on the day of the State Revenue and Expenditure Budget (APBN) ratification is carried out directly using the SPSS application.

Table 2. Descriptive Statistical Analysis Average Abnormal Return (AAR)

\begin{tabular}{ccccc}
\hline APBN & Minimum & Maximum & Mean & Std.Deviation \\
\hline 2010 State Budget & -0.016790 & 0.016665 & 0.001959 & 0.009515 \\
2011 State Budget & -0.009826 & 0.006573 & 0.000171 & 0.005193 \\
2012 State Budget & -0.009769 & 0.008584 & -0.000932 & 0.006153 \\
2013 State Budget & -0.007593 & 0.008188 & 0.000385 & 0.005154 \\
2014 State Budget & -0.014076 & 0.010896 & -0.000175 & 0.008561 \\
2015 State Budget & -0.014978 & 0.014588 & -0.000161 & 0.008008 \\
2016 State Budget & -0.022304 & 0.015073 & -0.001334 & 0.010824 \\
2017 State Budget & -0.002611 & 0.008613 & 0.001799 & 0.003297 \\
2018 State Budget & -0.009648 & 0.016431 & 0.000983 & 0.007508 \\
2019 State Budget & -0.016546 & 0.013951 & -0.000631 & 0.008299 \\
\hline
\end{tabular}

Source: Compiled by the author. 
The values minimum, maximum, mean, and standard deviation from the results of the analysis can be seen in the following table 2. Moreover, table 2 shows that the lowest value occurred in the approval of the 2016 State Budget (APBN), which was -0.022304 . The highest value of the average abnormal return (AAR) occurs during the ratification of the State Budget (APBN) for the Fiscal Year 2010, which is 0.016665 . The lowest average abnormal return (AAR) value occurs in the ratification of the 2016 State Budget (APBN), which is -0.001334 . The highest average value of average abnormal return arises in the event of the Revenue Budget approval. And State Expenditure (APBN) for Fiscal Year 2010 amounting to 0.001959

Descriptive statistical analysis for the Average Abnormal Return (AAR) value before and after the State Revenue and Expenditure Budget (APBN) ratification is carried out directly using the SPSS application. The values minimum, maximum, mean, and standard deviation from the results of the analysis can be seen in the following table 3 .

Table 3. Descriptive Statistical Analysis of Average Abnormal Return (AAR) Before and After theEvent of APBN Approval

\begin{tabular}{|c|c|c|c|c|c|c|}
\hline APBN & & $\mathbf{N}$ & Min & Max & Mean & $\begin{array}{c}\text { Std. } \\
\text { Deviation }\end{array}$ \\
\hline \multirow{2}{*}{2010} & Before & 5 & -0.008681 & 0.011457 & 0.002782 & 0.007962 \\
\hline & After & 5 & -0.005154 & 0.015550 & 0.000406 & 0.008586 \\
\hline \multirow[b]{2}{*}{2011} & Before & 5 & -0.002754 & 0.002678 & -0.000532 & 0.002442 \\
\hline & After & 5 & -0.006451 & 0.006829 & 0.000767 & 0.006347 \\
\hline \multirow{2}{*}{2012} & Before & 5 & -0.009710 & 0.011610 & -0.000733 & 0.008215 \\
\hline & After & 5 & -0.001703 & 0.003063 & 0.000664 & 0.002153 \\
\hline \multirow{2}{*}{2013} & Before & 5 & -0.007145 & 0.007417 & 0.001833 & 0.005510 \\
\hline & After & 5 & -0.004101 & 0.004971 & -0.000207 & 0.003740 \\
\hline \multirow[b]{2}{*}{2014} & Before & 5 & -0.010902 & 0.007228 & $-6.0 \mathrm{E}-7$ & 0.007004 \\
\hline & After & 5 & -0.010807 & 0.012106 & -0.000278 & 0.009613 \\
\hline \multirow{2}{*}{2015} & Before & 5 & -0.013091 & 0.003207 & -0.001298 & 0.006813 \\
\hline & After & 5 & -0.008755 & 0.013480 & 0.002366 & 0.007878 \\
\hline \multirow{2}{*}{2016} & Before & 5 & $-0,012149$ & 0.004848 & -0.001879 & 0.006290 \\
\hline & After & 5 & -0.015867 & 0.016359 & 0.000618 & 0.013893 \\
\hline \multirow[b]{2}{*}{2017} & Before & 5 & -0.001483 & 0.009694 & 0.002183 & 0.004559 \\
\hline & After & 5 & -0.002555 & 0,003699 & 0.000703 & 0.002303 \\
\hline \multirow{2}{*}{2018} & Before & 5 & -0.004073 & 0.002243 & 0.000202 & 0.002489 \\
\hline & After & 5 & -0.009554 & 0.011384 & 0.000905 & 0.008181 \\
\hline \multirow{2}{*}{2019} & Before & 5 & -0.009667 & 0.006802 & -0.001747 & 0.007183 \\
\hline & After & 5 & -0.004787 & 0.001594 & -0.001878 & 0,003147 \\
\hline
\end{tabular}

Source: Compiled by the author.

For hypothesis II, after the average abnormal return (AAR) value per day is obtained, then the average abnormal return (AAR) is grouped into two, namely the average abnormal return (AAR) before and the average abnormal return (AAR) after the event. The two groups of average abnormal return (AAR) are then used as the primary data to measure the level of statistical significance using the SPSS Ver application. 20. Moreover, descriptive statistics of average abnormal return (AAR) before and after the event of the ratification of the State Revenue and Expenditure Budget (APBN) for each fiscal year can be shown in Table 3. 
Based on a descriptive statistical analysis of the average abnormal return (AAR), variable before and after the event of the ratification of the State Revenue and Expenditure Budget (APBN), the lowest value of the average abnormal return (AAR) (before the event occurs in the ratification of the State Revenue and Expenditure Budget (APBN) for the Fiscal Year 2017) is -0.001483 . While the lowest value of the average abnormal return (AAR) after the event occurs in the ratification of the 2012 State Budget (APBN), which is -0.001703 . The highest value of the average abnormal return (AAR) before the event occurred in the ratification of the 2012 State Budget (APBN), which was 0.011610, while the highest value of the average abnormal return (AAR) after the event occurred was in the approval of the State Revenue and Expenditure Budget. (APBN) for the 2016 Fiscal Year, namely 0.016359.

On average, the lowest average abnormal return (AAR) value before the ratification of the State Revenue and Expenditure Budget (APBN) occurred in the 2014 fiscal year, which was -0.000007 , while the highest average value of the average abnormal return (AAR) was before the event. The State Revenue and Expenditure Budget (APBN) ratification occurred in the 2010 fiscal year amounting to 0.002782 . Meanwhile, on average, the lowest average abnormal return (AAR) value after the ratification of the State Revenue and Expenditure Budget (APBN) occurred in the 2014 fiscal year, which was -0.000278 , while the highest average value was the average abnormal return (AAR). ) after the event of ratification of the State Revenue and Expenditure Budget (APBN) occurred in the 2015 fiscal year amounting to 0.002366 .

The trading volume activity (TVA) is the ratio between the number of shares traded at a certain time to the number of shares issued. Average trading volume activity (ATVA) is the average trading volume of the sample companies' shares for each observation day. Average trading volume activity (ATVA) before and after and at the time of the ratification of the State Revenue and Expenditure Budget (APBN) can be seen in table 4. Descriptive statistical analysis for values Average Trading Volume Activity (ATVA) before and after the event the State Revenue and Expenditure Budget (APBN) ratification is carried out directly using the SPSS application. Moreover, The values minimum, maximum, mean, and standard deviation from the results of the analysis can be seen in the following table 4 .

Table 4. Descriptive statistical analysis of Average Trading Volume Activity (ATVA) Before and After the Event of APBN Approval

\begin{tabular}{ccccc}
\hline APBN & Minimum & Maximum & Mean & $\begin{array}{c}\text { Std.Devi } \\
\text { ation }\end{array}$ \\
\hline APBN 2010 & 0.047538 & 0.236548 & 0.108411 & 0.058620 \\
APBN 2011 & 0.037366 & 0.230259 & 0.106243 & 0.072094 \\
APBN 2012 & 0.035495 & 0.090348 & 0.055730 & 0.017868 \\
APBN 2013 & 0.040744 & 0,120599 & 0.078335 & 0.025847 \\
APBN 2014 & 0.051741 & 0.193793 & 0.095541 & 0.049079 \\
APBN 2015 & 0.024348 & 0.082153 & 0.049821 & 0.019959 \\
APBN 2016 & 0.029778 & 0.210451 & 0.095455 & 0.054387 \\
APBN 2017 & 0,034883 & 0,114249 & 0,077143 & 0,021636 \\
APBN 2018 & 0,008920 & 0,022235 & 0,014558 & 0,004318 \\
APBN 2019 & 0,006362 & 0,044675 & 0,023568 & 0,012977 \\
\hline
\end{tabular}

Source: authors processed. 
Based on descriptive statistical analysis on the average trading volume activity (ATVA) variable, it is known that the lowest average trading volume activity (ATVA) during the ratification of the State Revenue and Expenditure Budget (APBN) occurred in the 2009 fiscal year, which was 0.006362. Meanwhile, the highest ATVA occurred during the ratification of the State Budget (APBN) for the Fiscal Year 2010, amounting to 0.236548. On average, the lowest average trading volume activity (ATVA) value occurred during the ratification of the State Budget (APBN) for the Fiscal Year 2018, which amounted to 0.014558 , while the highest average value of average trading volume activity occurred during the Budget approval event. State Revenue and Expenditure (APBN) for Fiscal Year 2010 amounting to 0.108411 . moreover, the data descriptive statistical analysis can be seen in table 4.

\section{Hypothesis Testing Hypothesis Testing I}

The first hypothesis of this study is that there is an abnormal return significant around the ratification of the State Budget (APBN). However, before testing the hypothesis, it is variable abnormal return necessary to know whether this is normally distributed or not. This is done to determine the appropriate statistical test tools used to process data. According to the normality test results, abnormal data returns for five days before the ratification event until five days after the ratification event is normally distributed. The value asymp evidence this. sig. (2-tailed) obtained through data processing in the SPSS Version 20 application was recorded to be more than 0.05 . Therefore, these data can then be performed parametric statistical testing using the method one-sample t-test.

The results of the one-sample t-test are shown in Table 4 and Table 5. According to the analysis results using the one-sample t-test on the abnormal value return of stocks during the ratification of the State Budget (APBN) for the 2010-2014 fiscal year, there is an abnormal return significantly received by investors. Abnormal return is considered significant if the Sig. $<0.05$ in the 95 percent confidence level. These results indicate that the capital market reacts to the APBN approval event.

Table 5. Results of One-Sample t-Test Abnormal Return in 2010 - 2014

\begin{tabular}{ccccccccccc}
\hline & \multicolumn{2}{c}{ APBN 2010 } & \multicolumn{2}{c}{ APBN 2011 } & \multicolumn{2}{c}{ APBN 2012 } & \multicolumn{2}{c}{ APBN 2013 } & \multicolumn{2}{c}{ APBN 2014 } \\
\hline & $\mathrm{t}$ & Sig. & $\mathrm{t}$ & Sig. & $\mathrm{t}$ & Sig. & $\mathrm{t}$ & Sig. & $\mathrm{t}$ & Sig. \\
\hline $\mathrm{t}-5$ & 0,771 & 0,452 & 0,977 & 0,343 & $-0,398$ & 0,696 & 1,402 & 0,180 & 2,040 & 0,058 \\
$\mathrm{t}-4$ & 0,899 & 0,382 & $-0,146$ & 0,886 & 1,383 & 0,186 & 1,811 & 0,089 & 0,333 & 0,743 \\
$\mathrm{t}-3$ & $-1,963$ & 0,067 & $-0,349$ & 0,732 & $-1,367$ & 0,191 & 0,514 & 0,614 & $-3,142$ & 0,006 \\
$\mathrm{t}-2$ & $-3,915$ & 0,001 & 1,079 & 0,296 & 0,584 & 0,567 & $-1,735$ & 0,102 & 1,338 & 0,200 \\
$\mathrm{t}-1$ & 2,730 & 0,015 & 1,078 & 0,297 & 0,178 & 0,861 & 1,927 & 0,072 & 2,123 & 0,050 \\
$\mathrm{t} 0$ & 1,582 & 0,133 & 0,194 & 0,849 & $-0,042$ & 0,967 & $-2,158$ & 0,046 & $-0,021$ & 0,984 \\
$\mathrm{t}+1$ & $-0,190$ & 0,851 & $-2,670$ & 0,017 & $-1,676$ & 0,113 & $-0,059$ & 0,954 & 0,308 & 0,762 \\
$\mathrm{t}+2$ & 0,148 & 0,884 & $-0,577$ & 0,572 & $-1,866$ & 0,080 & 0,713 & 0,486 & $-0,928$ & 0,367 \\
$\mathrm{t}+3$ & $-0,677$ & 0,508 & 0,712 & 0,487 & $-0,686$ & 0,502 & $-1,002$ & 0,331 & 1,371 & 0,189 \\
$\mathrm{t}+4$ & 2,761 & 0,014 & 0,777 & 0,449 & $-2,643$ & 0,018 & 1,156 & 0,264 & $-3,002$ & 0,008 \\
\hline Source: author processed & & & & & & & &
\end{tabular}


SPSS analysis using a one-sample t-test for the event of ratification of the State Budget (APBN) for the Fiscal Year 2015-2019 also shows a significant abnormal return, except for the ratification of the State Budget (APBN) for the Fiscal Year 2018. These results can be seen in Table 6.

Table 6. Results of One-Sample t-Test Abnormal Return for FY 2015 - 2019

\begin{tabular}{ccccccccccc}
\hline & APBN 2015 & \multicolumn{3}{c}{ APBN 2016 } & \multicolumn{3}{c}{ APBN 2017 } & \multicolumn{2}{c}{ APBN 2018 } & \multicolumn{3}{c}{ APBN 2019 } \\
\cline { 2 - 12 } & $\mathbf{t}$ & Sig. & $\mathbf{t}$ & Sig. & $\mathbf{t}$ & Sig. & $\mathbf{t}$ & Sig. & $\mathbf{t}$ & Sig. \\
\hline $\mathrm{t}-5$ & 0,597 & 0,559 & 1,449 & 0,167 & 0,236 & 0,817 & $-0,335$ & 0,742 & $-3,616$ & 0,002 \\
\hline $\mathrm{t}-4$ & 0,834 & 0,416 & 0,243 & 0,811 & $-1,514$ & 0,149 & $-1,872$ & 0,080 & 1,721 & 0,105 \\
\hline $\mathrm{t}-3$ & $-0,504$ & 0,621 & $-0,951$ & 0,356 & $-0,833$ & 0,417 & $-0,456$ & 0,655 & $-0,839$ & 0,414 \\
\hline $\mathrm{t}-2$ & 1,022 & 0,322 & $-1,253$ & 0,228 & 2,447 & 0,026 & $-0,122$ & 0,904 & $-2,645$ & 0,018 \\
\hline $\mathrm{t}-1$ & $-2,196$ & 0,043 & $-3,266$ & 0,005 & 0,475 & 0,641 & $-0,111$ & 0,913 & 1,327 & 0,203 \\
& & & & & & & & & & \\
\hline $\mathrm{t} 0$ & 0,753 & 0,462 & $-1,537$ & 0,144 & 1,063 & 0,303 & 1,764 & 0,097 & 2,261 & 0,038 \\
& & & & & & & & & & \\
\hline $\mathrm{t}+1$ & 0,376 & 0,712 & 1,150 & 0,267 & 0,996 & 0,334 & $-1,696$ & 0,109 & $-0,248$ & 0,807 \\
\hline $\mathrm{t}+2$ & 0,457 & 0,654 & 1,602 & 0,129 & $-0,295$ & 0,772 & $-1,329$ & 0,203 & 0,252 & 0,804 \\
\hline $\mathrm{t}+3$ & $-3,170$ & 0,006 & 2,856 & 0,011 & 0,855 & 0,405 & 1,232 & 0,236 & $-0,738$ & 0,471 \\
& & & & & & & & & & \\
\hline $\mathrm{t}+4$ & $-0,294$ & 0,773 & $-1,940$ & 0,070 & 0,979 & 0,342 & 0,907 & 0,378 & 0,917 & 0,373 \\
\hline $\mathrm{t}+5$ & 2,868 & 0,011 & $-2,498$ & 0,024 & 0,385 & 0,705 & 0,671 & 0,512 & $-0,586$ & 0,566 \\
& & & & & & & & & & \\
\hline source: author processed & & & & & & & &
\end{tabular}

\section{Hypothesis Testing II}

the second hypothesis of this study is that there is an average difference in abnormal returns of significant before and after the events attestation State Budget (STATE BUDGET). Testing this hypothesis is done by looking for the average abnormal return (AAR) of all stock samples five days before and five days after the budget approval event. The average abnormal return (AAR) value between before and after the event is then analyzed using the paired-sample t-test in the SPSS version 20 application.

Table 7. Normality Test of Variable Data Average Abnormal Return

\begin{tabular}{llll}
\hline \multirow{2}{*}{ APBN } & \multicolumn{2}{l}{ Asymp. Sig. (2-tailed) } & After \\
\cline { 2 - 4 } & Before & 0.464 & Normal \\
\hline 2010 & 0.946 & 0.656 & Normal \\
2011 & 0.902 & 0.810 & Normal \\
2012 & 0.985 & 0.984 & Normal \\
2013 & 0.926 & 0.985 & Normal \\
2014 & 0.986 & 0.870 & Normal \\
2015 & 0.721 & 0.978 & Normal \\
2016 & 0.768 & 0.999 & Normal \\
2017 & 0.749 & 0.963 & Normal \\
2018 & 0.684 & 0.862 & Normal \\
2019 & 0.864 & &
\end{tabular}

Source: processed by the author 
Before testing the paired-sample t-test, as in the hypothesis testing stage, the data average abnormal return (AAR) is necessary to test for normality using the Kolmogorov Smirnov. The provisions in the normality test with a confidence level of 5 percent are if the sig value $\leq 0.05$, the data is not normally distributed. Meanwhile, if the sig value is $>0.05$, the data is normally distributed. The results of the normality test average abnormal return using Kolmogorov Smirnov in the SPSS version 20 application can be seen in Table 6. Based on the results of normality testing using the Kolmogorov Smirnov, it can be concluded that the overall data average abnormal return (AAR)has a normal distribution with a sig $>0$ value 05 . Therefore, these data can then be performed parametric statistical testing using the paired sample t-test.

Table 8 shows the results of a paired sample t-test average abnormal return (AAR) of APBN approval events from the fiscal year 2010 to the fiscal year 2019 using the SPSS Version 20 application. Apart from determining the $t$-count and Sig. Through the method paired sample $\mathrm{t}$-test, the $\mathrm{t}$ - table value also needs to be calculated to determine whether a hypothesis is accepted or not. The t-table value is computed using Ms. Excel with the formula $=\operatorname{TINV}(0.05,4)$ and produces an at-table value of 2.776 . The analysis results paired sample t-test on the average abnormal return (AAR) between before and after the APBN approval event are presented in Table 7 . Based on Table 7 , the $t$-count value for the ten APBN validation events ranged from -0.852-0.659 or less than the t-table value of 2.776. In addition, the test results also show the sig value. Ranged between 0.442-0.967, which is greater than 0.05 . Therefore, the conclusion that can be drawn is that there is no significant difference in the average abnormal return before and after the ratification of the State Budget (APBN) or rejecting Hypothesis II.

Table 8. Results of Paired Sample t-Test Average Abnormal Return (AAR) Event Ratification of APBN

\begin{tabular}{lllc}
\hline APBN & t-count & Sig. & Information \\
\hline 2010 & 0.519 & 0.631 & Hypothesis II denied \\
2011 & -0.385 & 0.720 & Hypothesis II rejected \\
2012 & -0.359 & 0.737 & Hypothesis II was \\
& & rejected \\
2013 & 0.659 & 0.546 & The hypothesis rejected \\
2014 & 0.042 & 0.968 & Hypothesis II rejected \\
2015 & $-0,852$ & 0,442 & Hypothesis II rejected \\
2016 & -0.321 & 0.764 & Hypothesis II rejected \\
2017 & 0.500 & 0.643 & Hypothesis II rejected \\
2018 & -0.169 & 0.874 & Hypothesis II rejected \\
2019 & 0.044 & 0.967 & Hypothesis II rejected \\
\hline
\end{tabular}

Source: processed by the author

\section{Hypothesis III Testing The third}

This study hypothesizes that there is a significant difference in the average trading volume activity before and after the ratification of the State Revenue and Expenditure Budget (APBN). The moderate trading volume activity (ATVA) of all stock samples for five days before and five days after the budgeting event is used to test this hypothesis. The paired-sample t-test in the SPSS version 20 application is then used to compare the average trading volume activity (ATVA) value before and after the case. 
Before testing the paired-sample t-test, such as in the testing stages of hypotheses I and II, data average trading volume activity (ATVA) needs to be tested for normality using the Kolmogorov Smirnov. The provision in the normality test with a confidence level of 5 percent is that if the sig value $\leq 0.05$, the data is not normally distributed. Meanwhile, if the sig value is $>0.05$, the data is normally distributed. The results of testing the normality of average trading volume activity (ATVA) using Kolmogorov Smirnov can be seen in table 9 .

Table 9. Normality Test of Variable Data Average Trading Volume Activity

\begin{tabular}{cccc}
\hline \multirow{2}{*}{ APBN } & \multicolumn{2}{c}{ Asymp. Sig. (2-tailed) } & \multirow{2}{*}{ Description } \\
\cline { 2 - 3 } & Before & After & \\
\hline 2010 & 0.710 & 0.912 & Normal \\
2011 & 0.878 & 0.897 & Normal \\
2012 & 0.950 & 0.946 & Normal \\
2013 & 0,990 & 0.582 & Normal \\
2014 & 0.487 & 0.845 & Normal \\
2015 & 0.930 & 0.982 & Normal \\
2016 & 0.798 & 0.943 & Normal \\
2017 & 0.869 & 0.823 & Normal \\
2018 & 0.919 & 1000 & Normal \\
2019 & 0.942 & 0.947 & Normal \\
\hline
\end{tabular}

Source: processed by the author

Table 10. Results of Paired Sample t-Test Average Trading Volume Activity (ATVA) Events Endorsement of APBN

\begin{tabular}{cccc}
\hline APBN & t-count & Sig. & Information \\
\hline 2010 & 3.790 & 0.019 & Hypothesis III accepted \\
2011 & -0.613 & 0.573 & Hypothesis III rejected \\
2012 & 2.039 & 0.111 & Hypothesis III rejected \\
2013 & 0.803 & 0.467 & Hypothesis III rejected \\
2014 & -1.090 & 0.337 & Hypothesis III rejected \\
2015 & -1.810 & 0.145 & Hypothesis III rejected \\
2016 & 0.654 & 0.549 & Hypothesis III rejected \\
2017 & 1.074 & 0.343 & Hypothesis III rejected \\
2018 & $-1,241$ & 0.282 & Hypothesis III rejected \\
2019 & $-2,753$ & 0.051 & Hypothesis III rejected \\
\hline
\end{tabular}

Source: processed by the author

According to the results of normality testing using Kolmogorov Smirnov, the overall data average trading volume activity (ATVA) has a normal distribution with a sig> 0.05 . Therefore, these data can then be performed parametric statistical testing using the paired sample t-test, apart from determining the t-count and Sig. Through the method paired sample $t$-test, the $t$-table value also needs to be calculated to determine whether a hypothesis is accepted or not. The t-table value is computed using Ms. Excel with the formula $=\operatorname{TINV}(0.05,4)$ and produces the at-table value of 2.776 . The following table 10 shows the results of the paired sample t-test average trading volume activity (ATVA) of the 
ratification of the State Revenue and Expenditure Budget (APBN) for Fiscal Years 20102019 using the SPSS Version 20 application.

The analysis results paired sample t-test on average trading volume activity (ATVA) before and after the State Revenue and Expenditure Budget (STATE BUDGET) ratification are shown in Table 10. Based on Table 10, the t-count value for the ten events of the ratification of the State Revenue and Expenditure Budget (APBN) ranges from -2,753 - 2,039 or less than the t-table value of 2.776, except for the event of ratification of the Year State Revenue and Expenditure Budget (APBN) 2010 budget which has an at-count value of 3,790 . In addition, the test results also show the sig value. The range is between $0.051-0.573$ or greater than 0.05 , except for the 2010 State Budget (APBN) ratification, which has a sig value-amounting to 0.019 .

According to the results of the paired sample t-test, it can be concluded that in the ratification of the State Revenue and Expenditure Budget (APBN) for the Fiscal Year 2010. (there is a substantial difference in the average trading volume activity before and after the event of ratification of the Income and Expenditure Budget). State (APBN) or receive H0. However, there was no substantial difference in the average trading volume activity before and after the State Revenue and Expenditure Budget (APBN) ratification for the 2011-2019 fiscal year or rejecting Hypothesis III.

\section{DISCUSSION}

\section{Discussion Hypothesis I}

The research using the event study approach on ten events of the State Revenue and Expenditure Budget (APBN) ratification shows that this event contains information that causes the Indonesian capital market to react. There were abnormal returns with significant positive and negative values from a number of incidents of ratification of the State Revenue and Expenditure Budget (APBN) under study. Katti, S. W. B. (2018) explains that the market reaction in an event study is calculated by using an abnormal return, which is an excess of the real yield against normal returns. Normal returns are the returns that investors expect (expectations) and occur when an event does not happen. With certain events, the yield will increase if the event is information that investors perceive as good (good news) and decrease if it is terrible news.

The existence of a positive abnormal return indicates that some market players consider this information on the ratification of the State Revenue and Expenditure Budget (APBN) to be good news. On the other hand, abnormal returns that have a negative value reflect the opinion of some market players that the information on the ratification of the State Revenue and Expenditure Budget (APBN) is bad news. However, the emergence of significant abnormal returns, both positive and negative, can be caused by profit-taking by market players to gain profits on share prices on the Indonesia Stock Exchange (IDX) around the ratification of the State Revenue and Expenditure Budget (APBN). This condition is consistent with the signaling theory, which notes that signals from information can change stock price movements. The signaling approach argues that in evaluating situations with risk and asymmetric information, market participants will consider signs or attributes from other parties before deciding. 
During the ratification of the 2018 State Budget (APBN), there was no significant abnormal return. This result is thought to be caused by the actions of Indonesian capital market players who carry out speculation that could benefit them on the days surrounding the ratification of the State Budget (APBN). Moreover, the absence of significant abnormal return can also be caused by market participants who are still waiting for the ratification of the government's continued policy on the policy plan outlined in the State Budget (APBN) for the Fiscal Year 2018.

\section{Discussion Hypothesis II}

Test results of the different reactions given by the market through the average abnormal return between before and after the event of the ratification of the State Revenue and Expenditure Budget (APBN) show insignificant results at $\alpha=5$ percent. Based on the test results, H0 is rejected or accepts H1. A difference in average abnormal return significance (AAR) did not occur in the ten events of the ratification of the State Revenue and Expenditure Budget (APBN) because market players had predicted the policy information contained in the State Revenue and Expenditure Budget (APBN) to be ratified. In this case, the signal possessed by budget information has been caught by market players long before the date of its approval.

This study supports previous research, i.e., Nascimento (2015), on the influence of the United States Federal Government's budget on the reaction of the country's capital market, particularly on the S \& P500 Index. This research shows that the budget approval event does not affect returns stock because market players have reacted first. The market tries to reduce the influence of the budget approval event so that the longer the fluctuation return will be weakened.

The United States Federal Government budgeting process is complex and unique. Several stages that must be passed are:

1. submission of a budget proposal from the President to the Congress,

2. budget approval by Congress after going through various debates and discussions, and

3. final approval by the President.

The budget preparation process will be even more complex if the elected President does not come from the same party as the majority of members of Congress. For the budget preparation process in Indonesia, Law Number 17 of 2003 states the steps for preparing and determining the State Revenue and Expenditure Budget (APBN).

1. The central government submits the critical points of fiscal policy and macroeconomic framework for the following fiscal year to the House of Representatives (DPR) by mid- May of the current fiscal year.

2. In preliminary discussions on the draft State Revenue and Expenditure Budget (APBN) for the following fiscal year, the central government and the House of Representatives (DPR) addressed the macroeconomic framework and critical points of budgetary policies proposed by the central government.

3. In August of the previous year, the Central Government submitted to the House of Representatives (DPR) a Draft Law on State Revenue and Expenditure Budget $(\mathrm{APBN})$, including financial notes and supporting documents. 
4. The House of Representatives (DPR) decides on the Draft Law on the State Revenue and Expenditure Budget (APBN) no later than two months before the fiscal year begins.

Looking at the stages of formulating and stipulating the State Budget (APBN), market players may have committed speculation during the initial drafting stage before the passage of the current year's APBN. Apart from that, market players are also waiting for the government's continued policy on the State Budget (APBN), which has been passed to make profitable investment decisions.

\section{Discussion of Hypothesis III}

Testing the different reactions given by the capital market through the average trading volume activity between before and after the event of the ratification of the State Budget (APBN) mostly shows insignificant results at $a=5$ percent. The insignificant difference in average trading volume activity (ATVA) is probably caused by market players who have anticipated the information contained in the ratification of the State Revenue and Expenditure Budget (APBN) in the early stages of its preparation.

$\mathrm{Hu}$, Q., Zhang, L., Zhang, W., \& Zhang, S. (2020), in his research on the influence of the government budget on the Portuguese capital market, states that the existing empirical evidence shows that the government budget affects stock returns not only at the time of publication or publication to the public but also when determining various decisions in the process to compile a document. Budget. In addition, in responding to information related to the State Revenue and Expenditure Budget (APBN) ratification, market players tend to take a wait-and-see action on follow-up policies formulated in the State Revenue and Expenditure Budget (APBN). Therefore, the transactions carried out by market participants after the event tend not to experience significant movements.

For the event of ratification of the State Budget (APBN) for Fiscal Year 2010, the test results indicate that the average trading volume activity (ATVA) before and after the event differs significantly. This means that market players consider that the event of the ratification of the State Budget (APBN) for Fiscal Year 2010 contains an informative value in the form of good news so that the number of traded shares (share trading volume) has increased compared to before.

\section{CONCLUSION, LIMITATIONS, AND SUGGESTIONS}

\section{Conclusion}

Based on the results of the testing and discussion that have been presented in the previous section, the conclusions of this study are as follows.

1. The State Revenue and Expenditure Budget (APBN) ratification for the $2010-2019$ fiscal year gave abnormal return market players an. Thus, the Indonesian capital market can be a capital market with a semi-strong form because the capital market's reaction through the abnormal returns received by market players around the ratification of the State Budget (APBN) shows the speed of the market in absorbing information received. However, the 2018 State Revenue and Expenditure Budget (APBN) test results did not offer any significant abnormal 
returns around the day the State Revenue, and Expenditure Budget (APBN) was ratified.

2. The State Revenue and Expenditure Budget (APBN) ratification for the 2010-2019 fiscal year. The absence of a noticeable difference between the average abnormal return (AAR) before and after the event led to allegations of speculative action by market players during the other State Revenue and Expenditure Budget (APBN) preparation stages before its approval.

3. There is no difference in average trading volume activity (ATVA) between before and after the State Revenue and Expenditure Budget (APBN) ratification for the 2011-2019 fiscal year. This is since some market players have made their investment decisions at the State Budget preparation stage before the endorsement. Some other market players have taken action to wait and see on further policies to be implemented by the government. However, for the State Budget (APBN) for the Fiscal Year 2010, there is a difference in average trading volume activity (ATVA) between before and after ratification.

\section{Limitation and suggestions}

Based on the research results that have been presented in the previous section, the following things can be taken into consideration, including:

1. The government, especially the Ministry of Finance, should prevent confusion in budget-related information that can lead to negative assumptions of market players that tend to encourage pessimism. In the capital market. Information that has not been verified should be clarified immediately to prevent further weakening of the stock price index.

2. The government, particularly the Ministry of Finance, also needs to formulate advanced policies from the various policies outlined in the State Revenue and Expenditure Budget $(\mathrm{APBN})$ quickly and accurately to reduce the uncertainty of market players.

3. In addition, it is hoped that the government (Ministry of Finance) will further increase the socialization of various advanced policies that have been described in the State Revenue and Expenditure Budget (APBN) to encourage investment in the capital market in line with the reduced uncertainty related to these policies.

4. Market players on the Indonesia Stock Exchange (IDX) can make the event of the ratification of the State Revenue and Expenditure Budget (APBN) as information in making decisions on their investment by remaining careful in analyzing relevant information and conditions of the Indonesian capital market so that the decisions taken are accurate.

5. Issuers listed on the Indonesia Stock Exchange can make the event of ratification of the State Budget (APBN) as information in making wise decisions related to finance, company work processes, business expansion, and other decisions that are closely related to the company's business continuity.

6. The average abnormal return (AAR) does not vary significantly before and after. 


\section{REFERENCES}

Castro-Iragorri, C. (2019). Does the market model provide a good counterfactual for event studies in finance?. Financial Markets and Portfolio Management, 33(1), 71-91. https:// doi.org/10.1007/s11408-019-00325-4

Chen, J. M. (2016). Modern portfolio theory. In Postmodern Portfolio Theory (pp. 5-25). Palgrave Macmillan, New York.

Considine, M., Nguyen, P., \& O'Sullivan, S. (2018). New public management and the rule of economic incentives: Australian welfare-to-work from job market signalling perspective. Public Management Review, 20(8), 1186-1204. https:// doi.org/10.1080/14719037.2017.1346140

Edirisinghe, C. 2017. Impact of Government Budget Announcement on Stock Market Sector Indices: Evidence from Colombo Stock Exchange. Journal of Finance and Accounting, Vol. 5 (6): 214 - 218. https:/ / doi.org/10.11648/j.jfa.20170506.12

Elad, F., \& Bongbee, N. (2016). Event study on the reaction of stock returns to acquisition news. Available at SSRN 2863243.

Fama, E. F. 1970. Efficient Capital Markets: A Review of Theory and Empirical Work. The Journal of Finance, Vol. 25 (2): 383-417. https:// doi.org/10.2307/2325468

1991. Efficient Capital Markets: II. The Journal of Finance, Vol. 46 (5): 1575 - 1617. https:// doi.org/10.1111/j.1540-6261.1991.tb04636.x

Guo, M., Kuai, Y., \& Liu, X. (2020). Stock market response to environmental policies: Evidence from heavily polluting firms in China. Economic Modelling, 86, 306-316. https:// doi.org/10.1016/j.econmod.2019.09.028

Gurkaynak, R. S., Kisacikoğlu, B., \& Wright, J. H. (2020). Missing Events in Event Studies: Identifying the Effects of Partially Measured News Surprises. American Economic Review, 110(12), 3871-3912. https:/ / doi.org/10.1257/ aer.20181470

Hu, Q., Zhang, L., Zhang, W., \& Zhang, S. (2020). Empirical Study on the Evaluation Model of Public Satisfaction With Local Government Budget Transparency: A Case From China. SAGE Open, 10(2). https:// doi.org/10.1177/2158244020924064.

Jogiyanto, H.M. 2017. Teori Portofolio dan Analisis Investasi. Yogyakarta : BPFE Universitas Gadjah Mada.

Kadji, Y. (2016). Metode Penelitian Ilmu Administrasi. Deepublish.

Katti, S. W. B. (2018). Pengaruh peristiwa politik (pemilu presiden dan pengumuman susunan kabinet) terhadap saham sektor industri di Bursa Efek Indonesia. Jurnal Ekonomi dan Manajemen, 1(2), 125-134. https:/ / doi.org/10.25273/capital.v1i2.2319

Kemu, S. Z. (2017). Literasi Pasar Modal Masyarakat Indonesia. Kajian, 21(2), 161-175.

Khanna, K. dan Gogia, N. 2014. A Pragmatic Study of Budget Announcements and Stock Market Performance: India, US, and UK Panorama. VSRD International Journal of Business and Management Research, Vol. 4 (2): 35 - 38. 
Nascimento, D.P.G.R. 2015. Effect of U.S. Federal Budget on S\&P500 Index [Disertasi]. Lisbon (PR): School of Business and Economic Catolica Lisbon.

Purba, F., \& Handayani, S. R. (2017). Analisis Perbedaan Reaksi Pasar Modal Indonesia Sebelum dan Sesudah Peristiwa Non Ekonomi (Studi pada Peristiwa Politik Pilkada DKI Jakarta 2017 Putaran Kedua). Jurnal Administrasi Bisnis, 51(1), 115-123.

Saraswati, N.M.A.W dan Mustanda, I.K. 2018. Reaksi Pasar Modal Indonesia terhadap Peristiwa Pengumuman Hasil Perhitungan Suara Pemilihan Umum dan Pelantikan Presiden Amerika Serikat. E-Jurnal Manajemen Universitas Udayana, Vol. 7 (6). https:// doi.org/10.24843/EJMUNUD.2018.v07.i06.p05

Sekaran, U., \& Bougie, R. (2016). Research methods for business: A skill building approach. John Wiley \& Sons.

Sorescu, A., Warren, N. L., \& Ertekin, L. (2017). Event study methodology in the marketing literature: an overview. Journal of the Academy of Marketing Science, 45(2), 186-207. https:// doi.org/10.1007/s11747-017-0516-y

Suganda, T. R. (2018). Teori dan Pembahasan Reaksi Pasar Modal Indonesia. Puntadewa.

Sugiyono, P. (2015). Metode penelitian kombinasi (mixed methods). Bandung: Alfabeta, 28.

Sujana, I. N. (2017). Pasar Modal yang Efisien. Ekuitas: Jurnal Pendidikan Ekonomi, 5(2), 3340 .

Taj, S. A. (2016). Application of signaling theory in management research: Addressing major gaps in theory. European Management Journal, 34(4), 338-348. https:/ / doi.org/10.1016/j.emj.2016.02.001

Public Documents and Legislation

Republik Indonesia. 1995. Undang-Undang Nomor 8 Tahun 1995 tentang Pasar Modal. 2003. Undang-Undang Nomor 17 Tahun 2003 tentang Keuangan Negara. 2016. Undang-Undang Nomor 9 Tahun 2016 tentang Pencegahan dan Penanganan Krisis Sistem Keuangan. 2017. Undang-Undang Nomor 15 Tahun 2017 tentang Anggaran Pendapatan dan Belanja Negara.

2015. Peraturan Menteri Keuangan Nomor 234/PMK.01/2015 tentang Tata Organisasi Kementerian Keuangan.

- 2015. Peraturan Menteri Keuangan Nomor 212/PMK.01/2017 tentang Perubahan atas Peraturan Menteri Keuangan Nomor 234/PMK.01/2015 tentang Tata Organisasi Kementerian Keuangan. 